\title{
Natalia Tarkowska
}

(iD https://orcid.org/0000-0003-4850-5086

Akademia Ignatianum w Krakowie

"Gong Gfodomora” - humorystyczny obraz atmosfery intelektualnej i obyczajowości panujacej w Zakładzie Przyrodoleczniczym dokțora Apolinarego Tarnawskiego w Kosowie

\section{Historia maszynopisu „Gong Głodomora”}

Unikatowy 21-stronicowy maszynopis został odkryty w 2016 r. przez Adama Śmiarowskiego podczas porządkowania spuścizny po jego dziadku Alfredzie Śmiarowskim. Wnuk - zafrapowany zagadkowym tekstem znalezionym w szafie - rozpoczął intuicyjne poszukiwania, wpisując w wyszukiwarkę internetową frazy „Kosów”, „Tarnawski” i inne słowa kluczowe pojawiające się w druku. Gdy uświadomił sobie rangę znaleziska, zwrócił się do mnie o pomoc w opracowaniu maszynopisu i przygotowaniu go do druku. Natychmiast pojawiło się pytanie: w jaki sposób maszynopis trafił w posiadanie Alfreda Śmiarowskiego? Odpowiedź na nie przyniosła rozmowa, którą Adam Śmiarowski przeprowadził ze swoim ojcem. Okazało się, że ojciec p. Adama pamięta wakacje spędzane na kuracji w Kosowie ze swoim ojcem Alfredem, podczas których wszedł on w posiadanie maszynopisu.

Alfred Śmiarowski urodził się 18 stycznia 1891 r. w Piotrkowie Trybunalskim. W 1902 r. rozpoczął edukację w Szkole Przemysłowej w Łodzi, która została przerwana w 1906 r. wskutek aresztowania pod zarzutem „rewolucjonizowania wojska” Śmiarowski był bowiem zaangażowany w konspiracyjną działalność Organizacji Bojowej Polskiej Partii Socjalistycznej (dalej: OB PPS). Do czasu zakończenia procesu Alfred został osadzony w X Pawilonie Cytadeli Warszawskiej. Rozprawa odbyła się 
w sali Sądu Wojennego nazywanej „salą śmierci”. W 1907 r. wyrokiem Sądu Wojennego dostał zakaz opuszczania miejsca zamieszkania i jednocześnie otrzymał „wilczy bilet" uniemożliwiający ukończenie edukacji oraz zdanie matury. Według rodzinnych wspomnień ten „łagodny” wyrok został zasądzony dzięki wstawiennictwu i „wykupowi” zorganizowanemu przez stryja Alfreda - Eugeniusza Śmiarowskiego - szanowanego i wybitnego adwokata ${ }^{1}$. Mimo represji Alfred cały czas pozostawał w związku z OB PPS oraz angażował się w działalność społeczną. W związku z zaistniałą sytuacją wykształcenie uzupełniał na kursach organizowanych przy Szkole Kupiectwa Łódzkiego (1908 r.), a następnie na prywatnych kursach buchalteryjnych Izraela Mantibanda (1911 r.). W latach 1909-1911 pracował w biurze swojego wuja, łódzkiego notariusza Eugeniusza Trojanowskiego. Od 1911 r. realizował się zawodowo w łódzkim oddziale Banku Handlowego jako pierwszy prokurent. Po 1914 r. zaangażował się w działalność Polskiej Organizacji Wojskowej. Alfred Śmiarowski zapisał się w historii bankowości jako autor publikacji Praktyczny informator dla posiadaczy weksli, z wykazem miejscowości i banków w Polsce (pięć wydań: Łódź 1923, 1927, 1928). Znał język rosyjski i niemiecki, interesował się także sanskrytem. Niestety, jego życie zostało brutalnie przerwane w dniu 30 listopada 1940 r., gdy został zamordowany przez Niemców ${ }^{2}$.

Jak zaklasyfikować maszynopis sporządzony w lecznicy doktora Tarnawskiego? Uzdrowiska i zdrojowiska posiadały zazwyczaj własne periodyki, które służyły głównie celom informacyjnym i reklamowym. Na ich łamach zamieszczano ogólne i szczegółowe informacje dotyczące samego uzdrowiska, jego urządzenia oraz środków leczniczych. Informowano także o środkach lokalnego transportu, zawiadamiano o planowanych rozrywkach (spektaklach, koncertach, wycieczkach), zamieszczano cenniki i reklamy poszczególnych pensjonatów. Prowadzono również bieżącą kronikę wydarzeń i podawano aktualną listę kuracjuszy. Dla uatrakcyjnienia treści w miarę możliwości zamieszczano krótkie opowiadania, felietony, wiersze oraz dowcipy. Pożądane były także ilustracje. Przykładem takich czasopism są: „Przegląd Zakopiański”, „Echo Krynickie”, „Zdroje Truskawieckie”, „Wiadomości informa-

${ }^{1}$ Eugeniusz Śmiarowski (1878-1932) - studiował prawo na Uniwersytecie Warszawskim, z którego został wydalony za udział w strajkach przeciw rusyfikacji, następnie studiował w Heidelbergu i Kazaniu. W latach 1905-1907 należał do Koła Obrońców w Sprawach Politycznych, w ramach którego bronił z powodzeniem bojowców OB PPS, m.in. Stefana Kierkowskiego. Od 1917 r. współtworzył polskie sądownictwo. Na przełomie 1919 i 1920 r. był wiceministrem resortu sprawiedliwości. W 1920 r. walczył w obronie Warszawy. Od 1920 r. należał do wolnomularskiej Wielkiej Loży Narodowej. Karierę polityczną rozpoczął w szeregach Stronnictwa Narodowo-Radykalnego, a następnie w Zjednoczeniu Stronnictw Demokratycznych. W 1922 r. został wybrany na posła Sejmu I kadencji (1922-1927) z listy PSL „Wyzwolenie”. W 1925 r. związał się z Partią Pracy, a od 1926 r. działał jako poseł bezpartyjny. Zob. A. Dobroński, Krasomówca rodem z Łomży, „Kontakty” 1982, nr 9, s. 11; L. Kania, Wspomnienie o adw. Eugeniuszu Śmiarowskim (1878-1932), „Palestra” 2005, nr 11-12, s. 138-142.

2 Archiwum rodzinne Adama Śmiarowskiego, Życiorys Alfreda Śmiarowskiego, rkps; Zbiory autorki, Korespondencja Adama Śmiarowskiego z autorką, 24 XI 2016 r.

${ }^{3}$ Wydawcą od 1900 r. był Związek Przyjaciół Zakopanego. Pismo drukowano w latach 1899-1906.

${ }^{4}$ Wydawcą i zarazem redaktorem naczelnym był Jarosław Sawczak w Krynicy. Pismo drukowano w latach 1926-1930. Funkcję kierownika literackiego pełnił Henryk Gralski. 
cyjne"5 oraz „Zaleszczyki. Przegląd uzdrowiskowo-turystyczny”. Wstępna analiza powstałego w kosowskiej lecznicy „Gongu Głodomora” pokazuje, że maszynopis nie jest typowym wydawnictwem uzdrowiskowym. Nie pełnił bowiem funkcji informacyjnej ani propagandowej, zaś jego jedynym celem było zapewnienie kuracjuszom rozrywki - „Gong” ma wyłącznie charakter satyrycznego periodyku literackiego. Pismo powstawało z inicjatywy pacjentów, którzy chcieli w ten sposób urozmaicić swoją kurację taką właśnie rozrywką.

W tym miejscu warto pokusić się o interpretację enigmatycznego tytułu maszynopisu. Pierwszy człon odnosi się do gongu, który doskonale znali pacjenci doktora Tarnawskiego. To właśnie donośny dźwięk gongu o poranku wyrywał kuracjuszy z błogiego snu i zmuszał do porannego brodzenia po rosie. Hałaśliwy gong towarzyszył pacjentom także przez cały dzień, przyzywając ich na kolejne etapy kuracji przewidziane w planie leczenia i zmuszając do ciągłej aktywności fizycznej ${ }^{7}$. Drugi człon tytułu pisma odnosi się zaś do słynnych „głodomorów Tarnawskiego" - jak powszechnie mawiano o pacjentach, którzy decydowali się na podjęcie kuracji postem. Tytuł zatem odnosi się do charakterystycznych elementów kosowskiej kuracji, które w świadomości pacjentów były nieodłącznie kojarzone z lecznicą doktora Tarnawskiego. Mamy tu także do czynienia z zabiegiem stylistycznym polegającym na zastosowaniu kontrastu wywołującego uśmiech, gdy wyobrazimy sobie gong - jako coś masywnego, w zestawieniu z głodomorem - osobą o anemicznym wyglądzie.

$\mathrm{Z}$ zawartego w edytowanym numerze tekstu pod tytułem „Dziesięciolecie głodu” dowiadujemy się, że minęło dziesięć lat odkąd ukazał się pierwszy numer „Gongu Głodomora”. Dotychczasowa kwerenda archiwalna nie przyniosła informacji o tym, czy zachowały się wcześniejsze i późniejsze numery pisma. Zaskakuje też fakt, że „Gong” nie zapisał się w pamięci byłych pacjentów lecznicy. Jedyna wzmianka o wydawaniu takiego pisma pojawiła się dopiero w 1950 r. na łamach emigracyjnych „Wiadomości". Autorką tego tekstu była Eugenia Kruk-Rostańska, która dosyć precyzyjnie przytoczyła słowa zawarte w omawianym tutaj drugim numerze „Gongu Głodomora”, co świadczy o tym, że była jego czytelniczką w czasie pobytu w lecznicy ${ }^{8}$. Jednak autorka nazwała maszynopis jednodniówką, co stoi w sprzeczności z zawartymi w treści maszynopisu uwagami redakcji. Co więcej, nie daje nam to odpowiedzi na pytanie, czy zachowały się inne numery pisma. Nasuwają się też kolejne pytania: czy „Gong Głodomora” ukazywał się regularnie? Kto był redaktorem pozostałych numerów i ile numerów ukazało się do 1939 r? Te pytania nadal pozostają otwarte. Można jedynie

${ }^{5}$ Wydawca Komisja Zdrojowa Truskawiec w Truskawcu, drukowane w latach 1926-1939. Zob. K. Puto, Zdroje Truskawieckie jako organ autokreacji kurortu wypoczynkowego, [on-line:] http://docslide.pl/documents/zdroje-truskawieckie-jako-organ-autokreacji-kurortu-wypoczynkowego.html\#, 16 II 2017.

${ }^{6}$ Wydawcą był Giewont Zdrój we Lwowie.

7 Dźwięki tam-tamu (gongu) były zastrzeżone wyłącznie do wzywania pacjentów na czynności ściśle związane z leczeniem, do posiłków pacjenci byli wzywani dźwiękiem dzwonu. W. Tarnawski, Mój ojciec, Londyn 1966, s. 145.

${ }^{8}$ E. Kruk-Rostańska, Jeszcze o Kosowie. Do redaktora „Wiadomości”, „Wiadomości” (Londyn) 1950, nr 18, s. 4. 
postawić hipotezę, że częstotliwość z jaką ukazywało się zakładowe czasopismo była uzależniona od sezonów leczniczych (wiosna, lato, jesień), jak również od tego, czy spośród pacjentów udało się zrekrutować chętnych do jego zredagowania. Ponadto na pierwszej i ostatniej stronie widnieje adnotacja informująca o tym, że pismo zostało wydane na prawach rękopisu, co oznacza, iż nie było profesjonalnie wydawane i powstawało jedynie w kilku lub też kilkunastu egzemplarzach przepisywanych na maszynie ${ }^{9}$.

Do rozstrzygnięcia pozostaje również kwestia autorstwa maszynopisu. Jak już wcześniej wspomniano, pismo było wspólnym dziełem pacjentów przebywających w danym czasie na kuracji. Na ostatniej stronie maszynopisu widnieje niezbyt czytelny podpis redaktora, co nie pozwala na jednoznaczne zidentyfikowanie osoby odpowiedzialnej za powstanie pisma ${ }^{10}$. Jednak z utworu pt. Na pana W. J. Zaleskiego, zamieszczonego w drugim numerze „Gongu Głodmora”, dowiadujemy się, że to właśnie Wojciech Zaleski ${ }^{11}$ jest redaktorem omawianego numeru: „Zielony pod oczami, długi na kształt drąga, / Nie kopie ani rąbie, redaguje "Gonga»"12. Prawdopodobnie w powstanie numeru zaangażowane były także osoby, które pojawiają się w treści zamieszczonych tam tekstów: Wit Tarnawski ${ }^{13}$, Kazimierz Wierzyński ${ }^{14}$, Wiktor Podoski $^{15}$, Stefan Norblin ${ }^{16}$, prof. Ignacy Chrzanowski ${ }^{17}$ oraz Alina Kwiecińska ${ }^{18}$. Ponadto $\mathrm{z}$ ostatniej strony maszynopisu dowiadujemy się również, że do pierwszego egzemplarza drugiego numeru „Gongu Głodomora” dołączono karykatury dr. Wita Tarnawskiego, Kazimierza Wierzyńskiego i prof. Ignacego Chrzanowskiego - autorstwa

9 Zob. s. 8, 30.

10 Ibidem, s. 30.

11 Wojciech Zaleski (1906-1960) - doktor prawa w zakresie nauk humanistycznych, historyk górnictwa i hutnictwa śląskiego, działacz Stronnictwa Narodowego, a następnie współzałożyciel Obozu Narodowo-Radykalnego, publicysta i redaktor „ABC. Nowiny codzienne” - na łamach tego pisma ukazywały się reklamy i artykuły o lecznicy Tarnawskiego.

12 Zob. s. 16 maszynopisu.

13 Wit Tarnawski (1894-1988) - syn Apolinarego Tarnawskiego i Romualdy z d. Zaremba, lekarz na początku lat 30. XX w. objął kierownictwo w lecznicy. Ponadto był pisarzem, publicystą i krytykiem literackim, znawcą twórczości Josepha Conrada. Zob. A. Pruszyńska, M. B. Topolska, Tarnawski Wit, [w:] Encyklopedia polskiej emigracji i Polonii, t. 5: S-Ż, red. K. D opi e rała, Toruń 2005, s. $109-110$.

14 Kazimierz Wierzyński (1894-1969) - poeta, prozaik i publicysta, który wraz z żoną przybył do lecznicy latem $1937 \mathrm{r}$.

15 Wiktor Podoski (1895-1960) - radca Ministerstwa Spraw Zagranicznych, dyplomata, autor szopek politycznych MSZ, publicysta, krytyk teatralny i krytyk sztuki. W czasie swoich pobytów w kosowskiej lecznicy organizował wydarzenia artystyczne, do których angażował pozostałych kuracjuszy. E. Kruk-Rostańska, op. cit., s. 4; N. Tarkowska, Lecznica narodu. Kulturotwórcza rola Zakładu Przyrodoleczniczego doktora Apolinarego Tarnawskiego na Pokuciu (1893-1939), Kraków 2016, s. $223,262$.

16 Stefan Norblin (1892-1952) - malarz, ilustrator, plakacista, scenograf i kostiumolog. Będąc w kosowskiej lecznicy, malował scenografie do wieczorów artystycznych. Zob. s. 29 maszynopisu.

17 Ignacy Chrzanowski (1866-1940) - historyk literatury, prof. Uniwersytetu Jagiellońskiego. Przyjaciel dra A. Tarnawskiego, stały bywalec kosowskiej lecznicy, gościł tam ponad trzydzieści razy. Odnotowany w wielu wspomnieniach z Kosowa jako dusza tamtejszego towarzystwa.

18 Alina Kwiecińska (1904-1946) - poetka i literatka, członkini Towarzystwa Literatów i Dziennikarzy, stała współpracowniczka „Kuriera Warszawskiego”. Zob. S. Łoza, Czy wiesz kto to jest?, Warszawa 1938, s. 406-407. 
wybitnego malarza Stefana Norblina. Niestety, odnaleziony maszynopis nie zawiera wspomnianych rysunków.

Edycja pisma, które w zamierzeniu autorów miało być frywolnym, a nawet karykaturalnym odzwierciedleniem efemerycznych stosunków panujących w placówce, jest zadaniem niesłychanie trudnym. Niestety, czas sprawił, że wiele znaczeń ukrytych w tekście przez twórców uległo zatarciu. Humorystyczne odniesienia do osób przebywających na kuracji, w czasie której powstał „Gong”, nie są zrozumiałe dla współczesnego odbiorcy tekstu. Nie jesteśmy w stanie zidentyfikować wielu z tych osób i sytuacji, by zanosić się śmiechem nad ich przywarami ujętymi przez talent obserwatorski i uszczypliwe pióro redaktorów, jak zapewne robili to ówcześni czytelnicy, którym dedykowano to pisemko. W wielu przypadkach nie sposób też jednoznacznie określić, czy osoby przywoływane na łamach maszynopisu były pacjentami bawiącymi w tamtym czasie na kuracji, czy też na potrzeby tekstu odwoływano się także do powszechnie znanych postaci funkcjonujących w ówczesnej przestrzeni publicznej. Świadomość trudności ze współczesną recepcją tekstu nie powinna nam przesłonić jego bezdyskusyjnych walorów. Zachowany maszynopis, jak żadne inne źródło, pozwala nam poczuć ulotną atmosferę intelektualną i poznać obyczajowość panującą w lecznicy. Pomimo tego, iż „Gong Głodomora” jest pismem satyrycznym, niewątpliwie stanowi znakomite studium życia kulturalnego w lecznicy doktora Tarnawskiego.

Omawiany maszynopis otwiera tekst stylizowany na fikcyjny wyrok sądu w Kokosowie, znajdującego się na terytorium Rzeczypospolitej Kokosowskiej - czyli na terenie Zakładu Przyrodoleczniczego w Kosowie. Sentencja wyimaginowanego wyroku nawiązuje do rygoru panującego w lecznicy, a zasądzony wyrok w postaci ciężkiej pracy fizycznej i szkockiej lewatywy jest drwiną ze stosowanych w niej metod, nie zawsze przyjemnych dla pacjentów. Ten zręczny zabieg literacki posłużył redakcji jako pretekst do usprawiedliwienia dłuższej przerwy w ukazaniu się nowego numeru. Jest też sygnałem dla czytelników, że treści zawarte w maszynopisie należy traktować z przymrużeniem oka, a na terytorium opisywanej Rzeczypospolitej Kokosowskiej rzeczywistość przeplata się z fikcją. Nadanie lecznicy statutu Rzeczypospolitej Kokosowskiej sugeruje również, że wkraczamy do autonomicznego świata, w którym panują odrębne prawa i zwyczaje. Kosowska lecznica była bowiem postrzegana zarówno przez pacjentów, jak i mieszkańców Kosowa jako swoista utopia wykreowana przez Apolinarego Tarnawskiego, która była niemal zupełnie oderwana od otaczającej ją rzeczywistości ${ }^{19}$.

$\mathrm{Na}$ koniec warto pokrótce przybliżyć historię miejsca, w którym powstał „Gong Głodomora”, by nakreślić historyczno-kulturowe tło jego powstania. Oficjalne otwarcie lecznicy nastąpiło w 1893 r. z inicjatywy doktora Apolinarego Tarnawskiego. Celem, który przyświecał jej stworzeniu, było psychiczne i fizyczne uzdrowienie polskiego społeczeństwa za pomocą przyrodolecznictwa. Na podstawie swoich doświadczeń doktor Apolinary wypracował oryginalną metodę opierającą się na prostych zabiegach z wykorzystaniem środków natury, takich jak: słońce, woda, ruch i powietrze.

19 N. Tarkowska, op. cit., s. 279. 
W skład metody wchodziły zabiegi hydropatyczne, gimnastyka, ćwiczenia oddechowe, kąpiele słoneczno-powietrzne, leczenie postem oraz higiena odżywiania oparta na jarskiej diecie. Kuracja miała nauczyć pacjentów racjonalnego trybu życia przez wyrobienie silnej woli i nabranie dobrych nawyków. Z tego powodu placówkę nieoficjalnie określano Wyższą Szkołą Życia ${ }^{20}$.

Od początku istnienia do 1914 r. w placówce spotykali się Polacy ze wszystkich trzech zaborów. Na jej terenie mogli oni swobodnie dyskutować o patriotycznych inicjatywach i przyszłym kształcie niepodległej Polski. Schronienie znajdowali tam także dysydenci polityczni z zaboru pruskiego i rosyjskiego. Zawierucha dziejowa spowodowana wybuchem I wojny światowej sprawiła, że zakład był zamknięty przez siedem lat, a jego ponowne otwarcie nastąpiło w wyniku nalegań byłych pacjentów ${ }^{21}$. Od 1922 do 1939 r. kosowska lecznica ponownie stała się popularnym miejscem wypoczynkowym polskiej elity. Bywali tam czołowi artyści, pisarze, poeci, uczeni, duchowni oraz politycy przez co placówka ta miała niebagatelne znaczenie dla polskiej kultury. Wkład intelektualny i artystyczny bywalców tego miejsca oraz nurt ideowy i propagowany w niej styl życia w znacznym stopniu stymulował bowiem rozwój ówczesnego życia kulturalnego ${ }^{22}$. Jeden $z$ byłych pacjentów lecznicy - Ignacy Wieniewski - pisał po latach następująco: „(...) Kosów nie był zwykłym uzdrowiskiem, jak Krynica czy Truskawiec. Był on cegiełką w gmachu kultury narodowej - piękną, wartościową, oryginalną i bardzo polską" ${ }^{23}$. Biorąc sobie do serca te słowa, tym bardziej warto pochylić się nad wytworem literackim zredagowanym przez pacjentów doktora Apolinarego Tarnawskiego.

Ze względu na charakter źródła do minimum ograniczono redakcyjne ingerencje $\mathrm{w}$ tekst. Zrezygnowano $\mathrm{z}$ rozbudowanego aparatu komentarzy, by uniknąć przytłoczenia tekstu głównego. Ograniczono się zatem do nielicznych korekt związanych $\mathrm{z}$ dostosowaniem do współczesnych zasad interpunkcji oraz usunięto niepozostawiające wątpliwości błędy, wynikające z ewidentnych pomyłek w druku. Wszystkie przypisy pochodzą od autorki edycji. Dla uzyskania przejrzystości tekstu, a także aby zaakcentować odrębność poszczególnych segmentów maszynopisu, wyszczególniono tytuły poprzez ich podkreślenie.

20 Zob. ibidem, s. 63-101.

2124 października 1914 r. dr Tarnawski został aresztowany przez Austriaków pod zarzutem przechowywania w lecznicy szpiegów rosyjskich, w wyniku czego skazano go na wyrok śmierci. Wyrok nie został wykonany, ale Tarnawski otrzymał zakaz powrotu do miejsca zamieszkania. Po zajęciu Kosowa przez wojsko rosyjskie budynki lecznicy zostały zarekwirowane na cele wojskowe, utworzono tam $\mathrm{m}$.in. szpital wojskowy. Zob. ibidem, s. 44-46.

22 Zob. ibidem, s. 203-228.

23 I. Wieniewski, Kalejdoskop wspomnień, Londyn 1970, s. 85. 


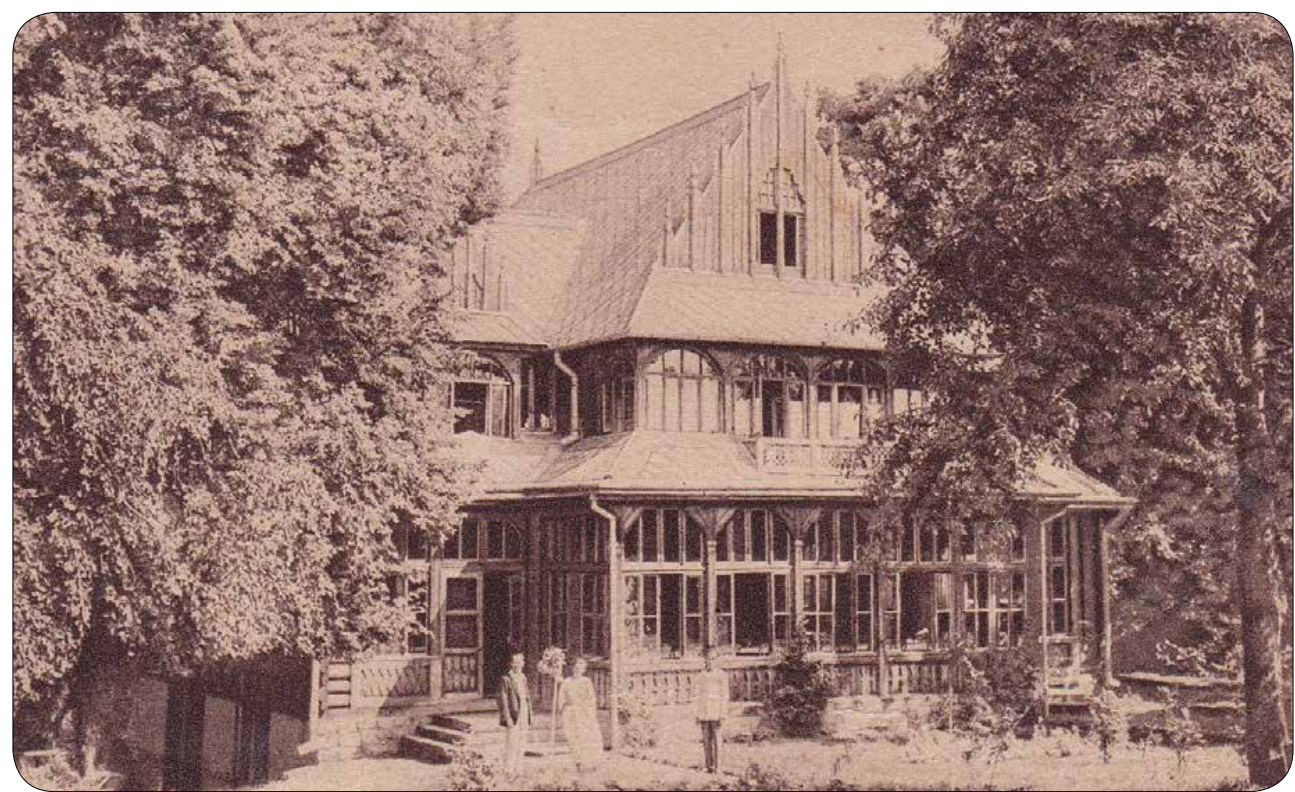

1. Jadalnia w lecznicy dra Apolinarego Tarnawskiego. Pocztówka, rotograwura drukarni św. Wojciecha w Poznaniu. Źródło: zbiory autorki.

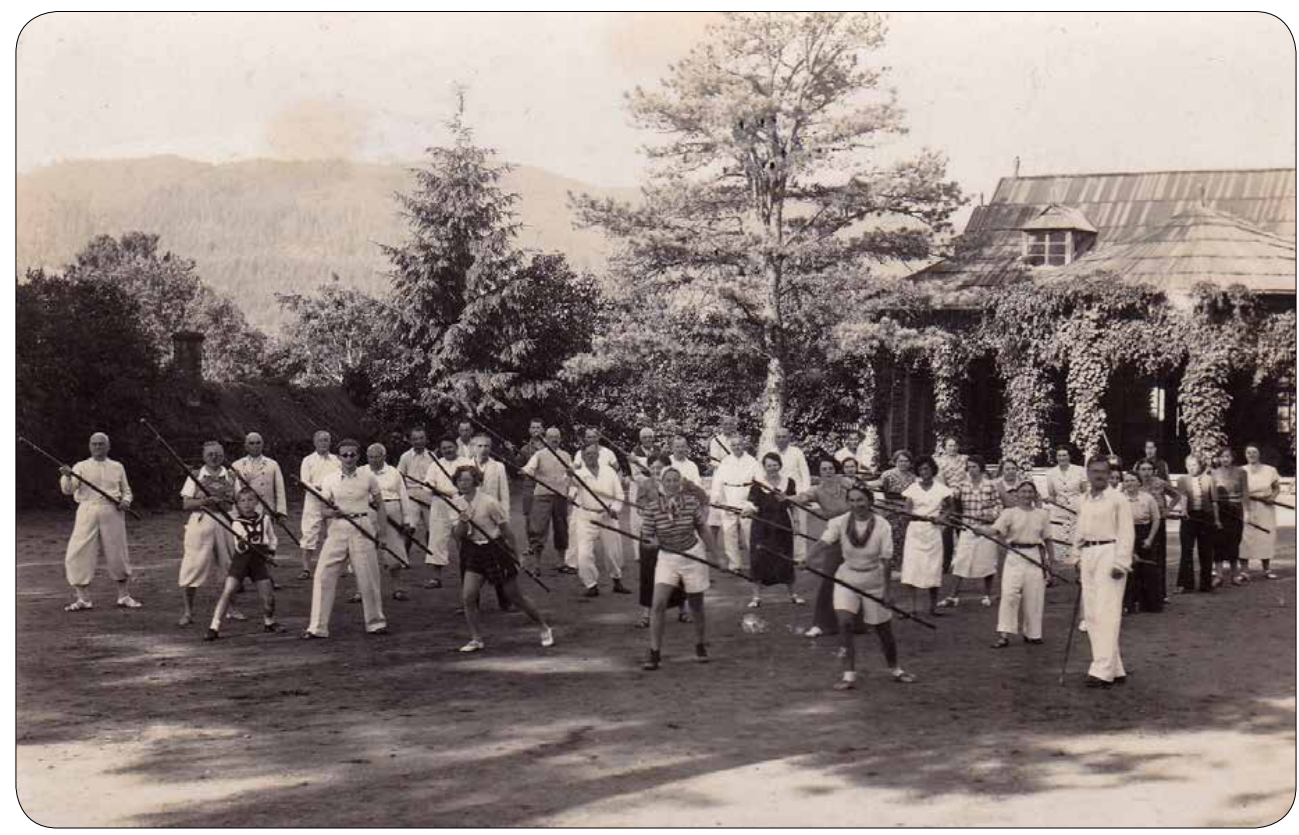

2. Gimnastyka w lecznicy dra Tarnawskiego w Kosowie. Fot. Mikołaj Seńkowski. Źródło: zbiory autorki. 


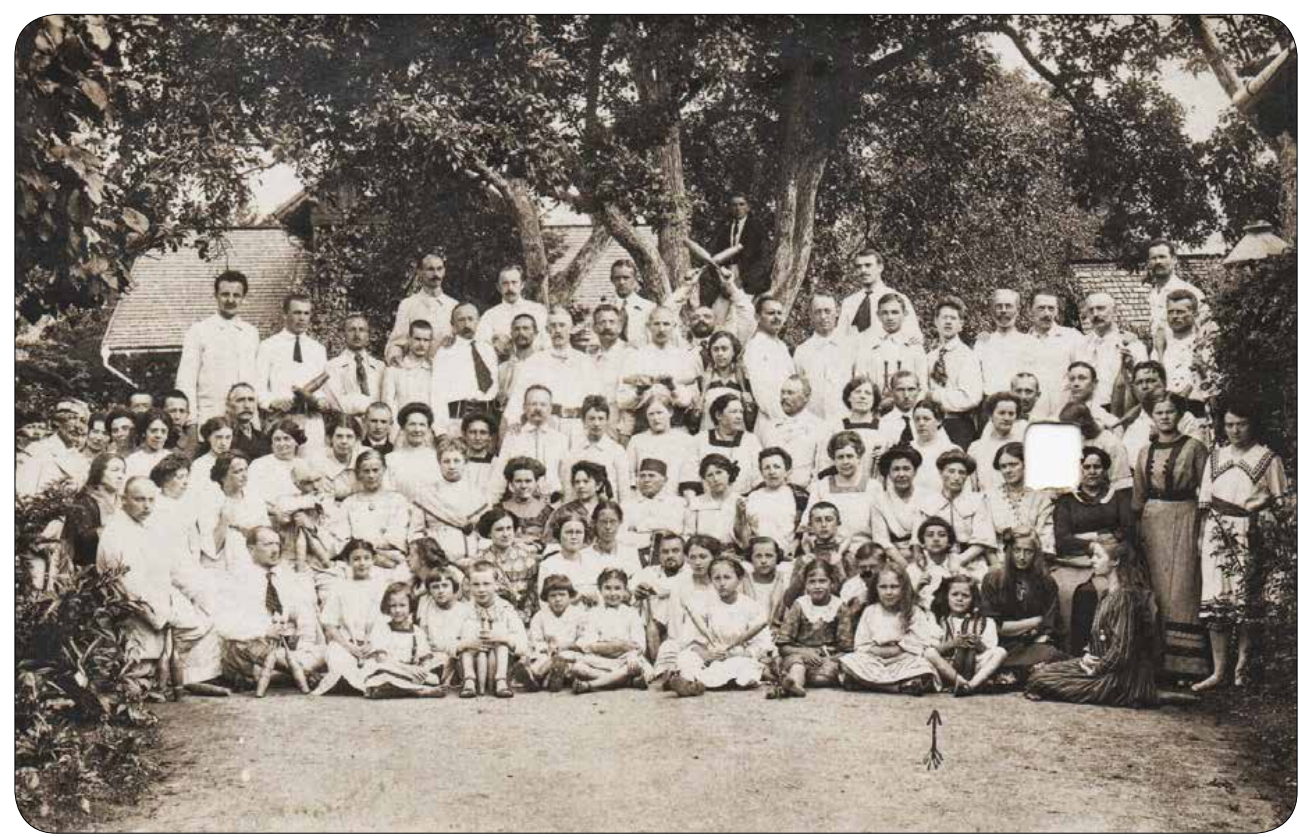

3. Pacjenci dra Tarnawskiego. Fot. R. Widepuhl, Kosów 1912. Źródło: zbiory autorki.

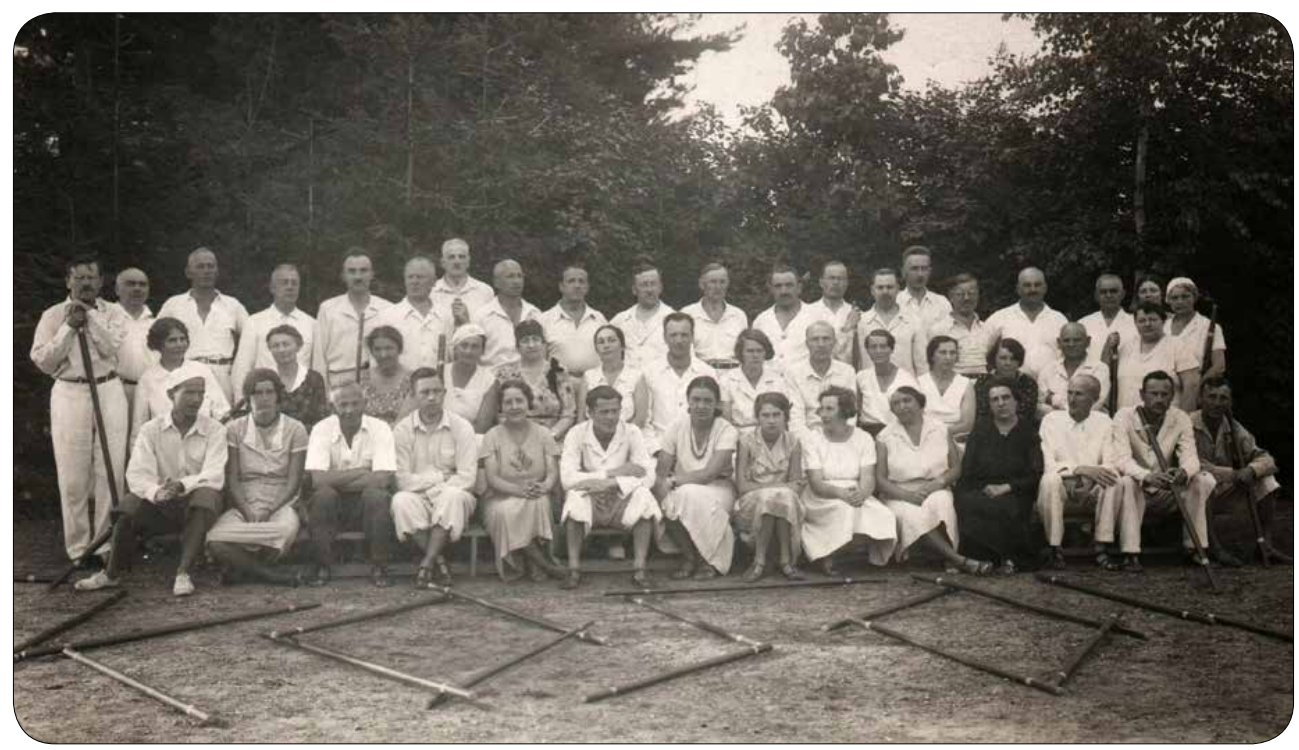

4. Pacjenci dra Tarnawskiego. Pierwszy z lewej stoi dr Wit Tarnawski. Lata 30. XX wieku. Źródło: zbiory autorki. 


\section{GONG GŁODOMORA}

Na prawach rękopisu.

$\operatorname{Nr} 2$

Kosów, dnia 23 sierpnia 1937 r.

rok XI.

Po konfiskacie nakład drugi.

Dłuższa przerwa w ukazaniu się naszego pisma nastąpiła z przyczyn od Redakcji i Administracji niezależnych. Przyczyny zwłoki wyjaśni czytelnikom naszym poniższy wyrok:

$\underline{\mathrm{C} 2 / \mathrm{K} / 8}$

$1937 \quad$ Kosów, dnia 20 sierpnia 1937 r.

W imieniu Rzeczypospolitej Kokosowskiej!

Sąd Ogrodniczy w Kokosowie, na posiedzeniu niejawnym dnia 1 kwietnia 1937 r. zapoznawszy się z treścią artykułów nadesłanych Redakcji pisma „Gong Głodomora”, a skonfiskowanych przez Urząd Prokuratorski, a w szczególności artykułów:

Ryby śpiewają u Truchanowicza ${ }^{24}$

Hej użyjmy salami!

Doktorze władaj sobą, oraz koniec wiersza

Pan Twardowski w Kosowie

dopatrzył się w nich znamion przestępstwa przeciwko artykułom kodeksu karnego kokosowskiego przewidzianych $\$ 111$ (o obrazę władz), 222 (o rozpowszechnianie fałszywych wieści, mogących wywołać niepokój), 333 (o podburzanie do zbrodni), 444 (zgorszenie publiczne), - i uchwalił konfiskatę powyższych artykułów zatwierdzić, treść ich obrócić na użytek władzy, autorów zaś skazać na ciężkie roboty fizyczne obostrzone szkocką wlewką co soboty.

Sędzia Ogrodowy Wikt Jarski m.p.

\footnotetext{
${ }^{24}$ Władysław Truchanowicz - właściciel hotelu i restauracji znajdującej się przy kosowskim rynku. Według wielu wspomnień to właśnie do jego restauracji wymykali się pacjenci dra Tarnawskiego, którzy nie wytrzymali rygorystycznej diety. Informator Ziemi Kosowskiej, Kosów 1935, s. 5.
} 


\section{DZIESIĘCIOLECIE GLODU}

Ostatni numer „Gonga Głodomorów” ukazał się w dniu 15 października 1936. Dziesięć lat mija odkąd podjęliśmy naszą żmudną pracę i dziś stajemy przed Czytelnikami z uczuciem dumy ze spełnionego obowiązku. „Gong Głodomora” rozbrzmiewa na cały kraj, nasze ideały stały się własnością ogółu, a nasze zasady weszły w krew i myśl nowoczesnego Polaka. Bez taniej samochwalby lecz z głębokim przekonaniem i zgodnie z sumieniem możemy rzec, że za naszą sprawą podciągnęliśmy głód wzwyż, przywróciliśmy mu dobre imię i nadaliśmy mu siłę, z którą muszą się liczyć wszystkie wrogie czynniki. Czym był głód przed dziesięciu laty i jakie było jego znaczenie? Zbędne byłoby rozpisywać się szeroko na te tematy, tak dobrze wszystkim znane. Niezbyt odległą jest przeszłość, kiedy znaczenie głodu podawano nam jako klęskę i nieszczęście kraju pod względem politycznym, społecznym i gospodarczym. Wrogie elementy przekręcając świadomie istotę rzeczy przypisywały głodowi szereg właściwości zgoła mu obcych. Zdrowy instynkt społeczeństwa nie dał się jednak oszukać i oto jesteśmy świadkami odrodzenia głodu i jego powszechnego rozwoju. Ruch odrodzeniowy, któremu służy nasze pismo, miał skromne początki. Gdy rozpoczynaliśmy naszą akcję apetyt był zjawiskiem nagminnym, a zastawiony stół obiektem wszędzie spotykanym. Podjęta przez nas walka natrafiała na ogromne trudności, które zdołaliśmy pokonać tylko dlatego, że byliśmy pewni zwycięstwa naszych ideałów i dobroczynnych skutków nadchodzącej ery. Dziś patrzymy jasno w przyszłość i pewni siebie kroczymy dalej na obranej drodze. Zwycięstwo nasze doprowadziło do przeobrażenia narodu. Głód brata głodnych i oto niedaleki jest czas, gdy będziemy świadkami osłabienia tarć społecznych i zaniku walki klas. Cała Rzeczpospolita będzie jednakowo głodna i skonsolidowana gorącym pragnieniem dalszego głodu. Jak jeden mąż staniemy pod sztandarem głodowania, a doniosłe skutki polityczne i gospodarcze tej jedności socjalno-dietetycznej nie dadzą długo czekać na siebie. Nad wrażą potęgą sąsiadów będziemy mieli tę wyższość, że 35 milionów mieszkańców Rzeczypospolitej będzie mogło w ciągu roku głodować przez 5-8 miesięcy, podczas gdy na Wschodzie i Zachodzie, obywatel nie będzie się mógł obejść bez codziennego jadła. Fakt ten stanie się podwaliną odrodzenia gospodarczego (vide "Gong Głodomora” nr 1). Oszczędności przeprowadzone przez nas na konsumpcję pokarmów podniosą w niezwykle wydatny sposób stan zamożności powszechnej, a użyte na cele gospodarcze pozwolą nam szybko prześcignąć zaawansowany Zachód Europy. Wspaniały i własnymi siłami uzyskany wzrost kapitalizacji wewnętrznej nie przeszkodzi nam bynajmniej w dążeniach do samowystarczalności gospodarczej. Przeciwnie, wzrost głodu pogodzi ze sobą sprzeczne dotychczas kierunki ekonomiczne: zwolennicy autarkii pójdą w jednym szeregu z przedstawicielami inicjatywy prywatnej, która nie krępowana żadnymi ograniczeniami co do możności głodowania, uzyska w tej dziedzinie rezultaty niedające się wprost przewidzieć. Nie koniec na tym. Prócz skutków politycznych, gospodarczych i kulturalnych, ruch głodomorski może będzie także miał doniosły wpływ na życie duchowe kraju. Typ Polaka odgłodzonego, który siłą woli potrafi powstrzymać się od schlebiania zmysłom, stanie się uosobieniem hartu 
i siły, wytrwałości i samozaparcia, najbardziej wartościowych cech charakteru. Z tym oto dobytkiem stajemy dziś, w dziesięciolecie naszej działalności, przed Czytelnikami. Hasła nasze są znane i proste. Niech idą w przyszłość, niech łączą naród, niech gromadzą miliony pod naszymi sztandarami ${ }^{25}$.

Żądamy wzrostu postu!

Za młodu do głodu!

Bez brzucha do ducha!

Głód początkiem nowej ery!

Mierz siły na spacery!

„Gong” do głodu wszystkich wzywa!

Niech żyje lewatywa!

Precz z apetytem!

Wszyscy za Witem ${ }^{26}$ !

\section{Głodomór a pisownia polska}

Nadzwyczajne posiedzenie Komisji ortograficznej Polskiej Akademii Umiejętności.

Z powodu sporu jaki powstał przy stole kokosowskim między dwoma członkami PAU o pisownię wyrazu głodomór, zwołane zostało w Krakowie nadzwyczajne posiedzenie Komisji ortograficznej z udziałem przedstawicieli Rządu, PAL ${ }^{27}$, Związków Dziennikarskich, Organizacji Handlowo-Przemysłowych, Rolniczych oraz innych kompetentnych czynników. Przy dyskusji nad pochodzeniem wyrazu, zdania znawców podzieliły się w sposób uderzający, zależnie od uprzedzeń, jakie poszczególni znawcy życia żywią do głodowania.

Profesor Słoński ${ }^{28}$ (Warszawa) twierdził, że wyraz ten pochodzi z Bolszewii, gdzie głodomory w czerezwyczajce dobrowolnie stają głową do muru, by raczej ginąć, niż znosić głodowe męki.

Profesor Lehr-Spławiński ${ }^{29}$ przeciwnie wywodzi tę nazwę z niemieckiego Gut $\mathrm{Hu}$ mor, ponieważ poszczący mają dziwnie pogodne miny.

${ }^{25}$ Tekst jest pamfletem na ideę uzdrowienia narodu, która przyświecała działalności dra Tarnawskiego. Kształtowanie silnej woli w pacjentach osiągał m.in. przez stosowanie głodówki, którą uważał za najdzielniejszą formę kuracji - uważał ją za swoiste katharsis dla ducha i ciała. Zob. N. Tarkowska, op. cit., s. 88-91.

${ }^{26}$ Mowa tu o Wicie Tarnawskim.

${ }_{27}$ Polska Akademia Literatury została utworzona w 1933 r. Powstała w celu podniesienia poziomu literatury polskiej, miała stanowić najwyższy organ opiniotwórczy w sprawach języka, literatury i kultury. Podejmowała działania we współpracy z rządem na rzecz kultury polskiej. Zasłużonym pisarzom i poetom przyznawała dwa odznaczenia: Złoty i Srebrny Wawrzyn Akademicki, zaś debiutanci mogli otrzymać Nagrodę Młodych. Jej członkami byli m.in.: Wacław Sieroszewski - prezes, Leopold Staff wiceprezes, Zofia Nałkowska oraz Kazimierz Wierzyński.

${ }_{28}$ Stanisław Słoński (1879-1959) - językoznawca, slawista, prof. Uniwersytetu Warszawskiego.

${ }_{29}$ Tadeusz Lehr-Spławiński (1891-1965) - językoznawca, slawista, prof. Uniwersytetu Jagiellońskiego i rektor w latach 1938-1939 i 1945-1946. 
Profesor Kazimierz Nitsch ${ }^{30}$ również sięga do pierwiastków niemieckich, ale w sensie odwrotnym: że głodomorom należy się słusznie Guter Hummer (homar), a kto tego nie uznaje jest idiotą.

Przedstawicielka PAL p. Nałkowska uważa prawdziwych głodomorów za erotycznych nędzarzy (geux d'amour).

Znany hodowca i sportsmen przeciwnie twierdzi, że po głodówce człowiek upodabnia się do znakomitego ogiera reproduktora Galtee Moore.

Generalny sekretarz Akademii ${ }^{31}$ radzi szukać początków głodowania w pobudce oszczędnościowej, jedynie bowiem pod tym warunkiem Akademia może obniżać honoraria i zachować w kasie Gold Mehr.

Redaktor Berezowski ${ }^{32}$ zawezwany telegraficznie z Kosowa, wnioskuje z tajemniczego rytuału głodomorów w samotniach po zabiegach wodnych, że stanowią oni wszyscy filiację loży dobrych murarzy (masonów)... Gute Maurer.

Przedstawiciel MWR i OP ${ }^{33}$ widząc taką rozbieżność zdań i obawiając się zgorszenia w społeczeństwie, które dziś bardziej niż kiedykolwiek dąży do zjednoczenia narodowego, zapowiedział, że całą Komisję skieruje do Miejsca Odosobnienia w Kokosowie celem przestudiowania głodówki już nie metodą filologiczną, ale doświadczalną.

$\underline{\text { Pan Twardowski w Kosowie }}$

Klepią, tupią, skaczą żwawo

„Nogi zginać! Ręce wznosić!

Wdech i wydech dziurką prawą

Raz i dwa i trzy i - dosyćs"

A Chrzanowski ${ }^{35} \mathrm{w}$ pierwszym rzędzie

Huka, fuka w swoim guście

Dogaduje wciąż i zrzędzi

Doktorowi nie przepuści:

${ }^{30}$ Kazimierz Nitsch (1874-1958) - językoznawca, twórca dialektologii polskiej, prof. Uniwersytetu Jagiellońskiego, prezes Polskiej Akademii Umiejętności, wiceprezes Polskiej Akademii Nauk.

31 Mowa tu o Juliuszu Kaden-Bandrowskim (1885-1944) - pisarzu, publicyście, kapitanie Wojska Polskiego, sekretarzu generalnym Polskiej Akademii Literatury. Ojciec Kadena, Juliusz Bandrowski doktor medycyny, przyjaźnił się z A. Tarnawskim, z którym wydawał miesięcznik „Zdrowe Życie”, od 1914 r. był wspólnikiem spółki akcyjnej Lecznica dra Tarnawskiego w Kosowie, w 1917 r. wspólnie prowadzili oni wykłady z przyrodolecznictwa w Krynicy.

32 Zygmunt Berezowski (1891-1979) - dziennikarz, publikował teksty m.in. w „Myśli Narodowej”, redaktor „Polityki Narodowej”, polityk Stronnictwa Narodowego, poseł na Sejm I-III kadencji (19221935), sekretarz Polskiego Towarzystwa Opieki nad Kresami, minister spraw wewnętrznych w emigracyjnym rządzie Tomasza Arciszewskiego. Endecja postrzegała masonerię jako wroga Polski. W sierpniu 1937 r. Berezowski był w lecznicy razem z Romanem Dmowskim i Tadeuszem Bieleckim.

${ }_{33}$ Ministerstwo Wyznań Religijnych i Oświecenia Publicznego.

34 Fragment opisuje gimnastykę prowadzoną w lecznicy.

35 Mowa tu o prof. Ignacym Chrzanowskim. 
Dobry wieczór! To już było!

Głębiej! Prędzej! Czas na kawę!

Co się pani dzisiaj śniło?

Dziękujemy za zabawę!

Na kolegę z Akademii

Co milczkiem robił przysiady

Sypie słowy zelżywemi

„Pewno zjadł pan dwa obiady”?!

Prałatowi co pół brzucha

Stracił świeżo na głodówce

Chlast jęzorem koło ucha

Któż poskromi tego mówcę?36

Nagle zamilkł... czy go znudzili

Oklepaną anegdotą?

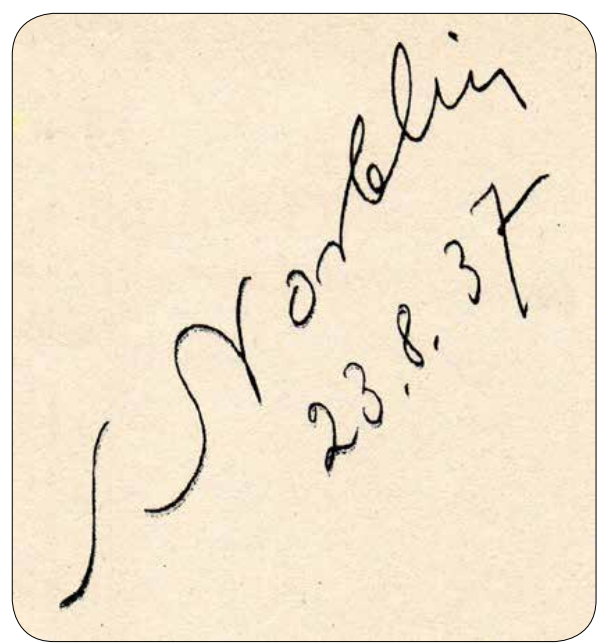

5. Autograf Stefana Norblina. Źródło „Gong Głodomora” 1937, nr 2, s. 6.

Czy źle spał? Bo od tej chwili

Ziewa wciąż jak hipopotam

I zaraziłby tym ziewem

Całą dziarską brać kosowską

Gdy w tem ujrzał tuż pod drzewem

Nadobną panią... Śmieszkowską

Wabik był w rozwódce na dnie

Wabik zresztą i na wierzchu

Spłonił się Chrzanowski ładnie

I... spotkali się o zmierzchu.

I gdzieś znikli. Gdzie nie powiem

Choćby o to mnie błagano

Tajemnica to... albowiem

Resztę mi... skonfiskowano! ${ }^{37}$

W czasie krótko zresztą trwających parodniowych deszczów w Kokosowie jeden $z$ kuracjuszy zabłądził w bibliotece domu zdrojowego, a nie mając innego zajęcia wobec podanego do publicznej wiadomości programu dnia zabrał się do przejrzenia

${ }^{36} \mathrm{Na}$ marginesie maszynopisu adnotacja: „Do pierwszego egzemplarza «Gonga Głodomora» nr 2 dołączono oryginalny rysunek przedstawiający profesora Chrzanowskiego - pędzla S. Norblina”.

${ }^{37} \mathrm{Na}$ szóstej stronie maszynopisu, obok frywolnego wiersza widnieje autograf Stefana Norblina, co może sugerować, że był on jego autorem i umieścił swój podpis obok utworu na prośbę Alfreda Śmiarowskiego. 
kurzem pokrytej biblioteki ${ }^{38}$. Wśród zapylonych książek na tematy higieniczne znalazł przeszło stuletni „Sztambuch”. Między innymi więcej i mniej udałymi zapiskami znalazł następujące, które czytelnikom naszym podajemy:

Nam jadać zakazano...

\section{A. Mickiewicz}

Gdym zamknięty w parówce pocił się na grzechy

Urągał mi kolega. Niech waść nie urąga

Gorzej się pocą dla waszej uciechy

Redaktorowie „Gonga”.

$$
\text { X. B. W. (Krasicki) }{ }^{39}
$$

Daremne żale, próżny trud

Upewniam cię bogini

Zbyt bujnym kształtom żaden głód

Nie wróci dawnej linii.

$$
\text { Asnyk }
$$

Gdybym był starszy kochanie

Bardziej wytarty

Siedzielibyśmy w altanie

Trawilibyśmy śniadanie i grali w karty.

Ale żem jeszcze nie piernik

Owszem taternik

Więc $\mathrm{z}$ buduarów i alków

Zapraszam was na Michałków ${ }^{40}$

Na grzybobranie.

$$
\text { Asnyk }
$$

Jest w czwartki i w niedziele w Zakładzie muzyka

Jest Gold i Petersburski ${ }^{41}$, kwintet Kubylika ${ }^{42}$

${ }^{38}$ Biblioteka znajdowała się w „Starym Domu” - budynku starej greckokatolickiej proboszczówki, która była pierwszym budynkiem zaadaptowanym na potrzeby lecznicy. W $1933 \mathrm{r}$. zbiory biblioteczne wynosiły ok. trzy tysiące tomów. A. Tarnawski, Program Zakładu Przyrodoleczniczego Dra Tarnawskiego w Kosowie k. Kołomyi Młp. Wsch., Lwów 1933, s. 9.

${ }_{39}$ X.B.W., czyli Książe Biskup Warmiński to kryptonim, którym posługiwał się Ignacy Krasicki.

${ }^{40}$ Michałków (815 m n.p.m.) - pacjenci Tarnawskiego chętnie udawali się na szczyt Michałkowa, by podziwiać panoramę miasta oraz okolicznych gór. Zob. H. Gąsiorowski, Przewodnik po Beskidach Wschodnich, t. 2, Lwów-Warszawa 1933, s. 262-263.

${ }^{41}$ Orkiestra Artura Golda i Jerzego Petersburskiego założona w 1925 r.

${ }^{42}$ Osoba niezidentyfikowana. 
Nad wszystkie orkiestry, aż psi wyją z wioski, Duet: gdy chrapie Schmatloch ${ }^{43}$ a gwiżdże Podoski ${ }^{44}$.

Wacław Potocki

Błachnio $^{45}$ i Masny

W jednej stali willi

Razem wstawali

Razem się leczyli.

Masny głodował

Lecz dam za to szyję

Nim Masny schudnie

Błachnio nam utyje.

Fredro

Przy głodówce w tem ambaras

Aby puścić wszystko naraz.

Boy-Żeleński

Kiedy cię rozboli główka

To pomoże nasiadówka.

Chrzanowski

Ktoś wrzeszczy w szkockim natrysku

Jakby go bili po pysku.

Jan Sotor Rozbicki ${ }^{46}$

Opłakane skutki profesorskiego... zacietrzewienia i plotkarstwa

W tych dniach profesor Chrzanowski znalazł w aligatorni męskiej kilka podejrzanych ulotek, podrzuconych widocznie przez jednego z kuracjuszy. Przy bliższym zbadaniu,

${ }^{43}$ Osoba niezidentyfikowana.

${ }^{44}$ Mowa tu o Wiktorze Podoskim.

${ }^{45}$ Prawdopodobnie mowa tu o Aleksandrze Błachnio - dwudziestoletnim (w 1937 r.) chłopaku z małorolnej rodziny chłopskiej mieszkającej w Prandocinie, który ukończył siedem klas szkoły powszechnej i marzył o karierze pisarza, ale z powodu warunków społecznych wrócił na wieś wypasać krowy. Talent młodzieńca dostrzegł Stanisław Piasecki - redaktor pisma „Prosto z Mostu” - i postanowił sprowadzić go do Warszawy, posyłając go tam do szkoły. Na łamach „Prosto z Mostu” opublikowano reportaż Przygody stypendysty i opowiadanie Książka i krowy, jego autorstwa. Jest prawdopodobne, że pod wpływem tych publikacji i za sprawą wstawiennictwa Piaseckiego Tarnawscy przyjęli młodzieńca na darmową kurację. W lecznicy oferowano darmowe lub tanie pobyty literatom, artystom i działaczom społecznym w trudnym położeniu materialnym. S. Piase cki, O imienniku z Świętego Krzyża, „Prosto z Mostu” 1937, nr 37, s. 1; K. Zbyszewski, Stanisław Piasecki, [w:] Straty kultury polskiej, t. 1, red. A. Ordęga, T. Terlecki, Glasgow 1945, s. 370.

${ }^{46}$ Prawdopodobnie jest to nawiązanie do twórczości Sotera Antoniego Rozbickiego, którą uważano za grafomańską. 
ulotki okazały się być korektą dzieła historycznego profesora Konopczyńskiego ${ }^{47}$, którą ów niebacznie zostawił na kąpieli słonecznej. Oburzony takiem nieszanowaniem zasad higienicznego próżnowania, profesor Chrzanowski pobiegł do dr. Wita Tarnawskiego i dał mu corpus delicti. W tekście znalazły się rzeczy okropne: że konfederaci barscy na emigracji żywili się jeden wyłącznie chlebem, drugi wyłącznie kaszą i że oblężeni na Wawelu, jak pisze w swym dzienniku płk. Galibert: „komendant dał nam wielki bankiet: po wielu potrawach $\mathrm{z}$ koniny podano pasztet $\mathrm{z}$ kocich krzyżów, z siedmiu wron i osiemdziesięciu wróbli" - i jednak nikt nie umarł. Dr Wit przypomniawszy sobie, że historia jest magistra vitae, postanowił odkrycie to zastosować w Kokosowie. Od poniedziałku 23 sierpnia w dnie bezmięsne kokosowici otrzymywać będą tylko chleb lub kaszę, a w niedziele zamiast kurcząt pasztety $\mathrm{z}$ wron i srok, niszczących tutejsze sady. Konsternacja w Zakładzie jest powszechna. Nieszczęsnym profesorom grozi wybicie szyb, to też mieszkania ich są otoczone podwójnym kordonem: administracja strzeże ich przed lynchem, kuracjusze pilnują, czy im wdzięczny Zakład nie dostarcza pokątną drogą przysmaków.

\section{OBELGI}

Na pana W. J. Zaleskiego

Zielony pod oczami, długi na kształt drąga,

Nie kopie ani rąbie, redaguje "Gonga”,

Bez łopaty i piły - cieszy się obłudnie

Że od samego pióra, jak literat, chudnie.

Na pana Norblina ${ }^{48}$

Przybył Anglik - świetna rasa

Szyk, sznyt, rozmach, pierwsza klasa,

Tenis, pędzel, narty, kajak,

Prawie mistrz i prawie knajak,

Z wiankiem kobiet wciąż u szyi -

Do Kosowa... z Kołomyi.

Na pannę I...

Od samego rana

Lata rozebrana

$\mathrm{Z}$ zasad sobie kpi,

${ }^{47}$ Władysław Konopczyński (1880-1952) - historyk, prof. Uniwersytetu Jagiellońskiego, poseł na Sejm I kadencji (1922-1927), członek Polskiej Akademii Umiejętności. W czasie swoich pobytów w Kosowie profesor wygłaszał wykłady oraz pracował także nad Polskim słownikiem biograficznym. W. Tarnawski, op. cit., s. 153.

${ }^{48}$ Rymowanka nawiązuje do życiorysu Stefana Norblina, który wychowywał się w Anglii, ale także do popularnego wówczas powiedzenia „Anglik z Kołomyi”, które było cynicznym określeniem używanym w stosunku do osoby z prowincji udającej bywalca zachodnich salonów. 
Trochę jak Walkiria

Trochę jak Diana

Nasza panna I.

Łamać dęby, mury -

Z tym jej do figury,

To jest dla niej tło:

Idealny model

Od dołu do góry

Dla dłuta Despiaux ${ }^{49}$.

$\underline{\text { Na pana Wita Tarnawskiego }}^{50}$

Latem doktor, zimą pisarz,

Na Kosowie król i cysarz,

Leczy, puk, bada, maca,

Silna wola, wielka praca,

Duch wzniesiony do potęgi!

Zapisuje całe księgi

Notat, recept i bez lęku

Najstraszniejszych trzyma w ręku

I drży tylko gdy wieczorem

Staje biedak przed Seniorem ${ }^{51}$.

Dzeus grzmi groźnie: Celu! ${ }^{52}$ Wicie!

Co się dzieje, czy widzicie?!

Jedzą, piją, lulki palą,

Wcale się nie doskonalą!

Tutaj sobą nikt nie włada

Po to Zakład się zakłada?!

I bolących ran dotyka:

Dietetyka, gimnastyka

Oddech, praca, lewatywa! -

Dzeus się gniewa, gromów wzywa

${ }^{49}$ Właściwie Charles Despiau (1874-1946) - francuski rzeźbiarz i rysownik.

${ }^{50}$ Utwór nawiązuje do konfliktu między drem Tarnawskim i jego synem, od którego oczekiwał zupełnego poświęcenia na rzecz zakładu i nie akceptował jego literackich aspiracji. Zob. W. Tarnawski, op. cit., s. 47, 68-69.

${ }^{51}$ Pacjenci lecznicy używali określenia „senior”, gdy mówili o drze Apolinarym Tarnawskim, dla odróżnienia od młodego dra - Wita Tarnawskiego.

${ }_{52}$ Celina Tarnawska-Busza (1905-1999) - córka Apolinarego Tarnawskiego i Romualdy z d. Zaremba, inżynier Wydziału Rolniczo-Leśnego Politechniki Lwowskiej w Dublanach, działaczka społeczna. W kosowskiej lecznicy odpowiadała m.in. za prowadzenie gimnastyki dziecięcej. M.B. Topolska, Tarnawska Busza Celina, [w:] Encyklopedia polskiej emigracji..., t. 5, s. 108-109. 
I przypiera groźnie Wita:

Dosyć tego! Basta! Kwita!

Tobie wszystko inne w głowie

Tylko nie Zakład w Kosowie:

Artykulik w miesięczniku,

Fiku-miku w „Tygodniku”,

O podróżach, o Conradzie,

"Podbipięta”54, „Prosto z mostu ${ }^{55 ”, ~}$

Tylko nic a nic w Zakładzie!

Jak ci kopnę miesiąc postu,

Pojmiesz - bo ty na to czekasz

Czyś ty pisarz czy też lekarz

I zakończysz rzecz rad nie rad

Przy pomocy bożej łaski:

Obiit literat

Natus est Tarnawski ${ }^{56}$.

Kaw. ${ }^{57}$

EPOKOWE WYDARZENIE W KOKOSOWIE ${ }^{58}$

Głosy najważniejszych agencji telegraficznych świata.

KAT

Kosowska Agencja Telegraficzna

18 VIII 1937

Z zakładu Dra Tarnawskiego donoszą, że dzisiejszą pocztą południową dostarczono jednemu z kuracjuszy przesyłkę z żywym zwierzęciem. Na paczce widniał napis: Kazimierz Wierzyński, zawartość prosię.

${ }^{53}$ Wit Tarnawski zadebiutował jako krytyk literacki na łamach „Tygodnika Ilustrowanego”, analizując twórczość Josepha Conrada.

54 „Podbipięta” - tygodnik pod red. Jana Rembilińskiego, wydawany w Warszawie w latach 1936-1937.

55 Wit Tarnawski publikował eseje krytyczne i recenzje m.in. w endeckim czasopiśmie literackim „Prosto z Mostu”, redagowanym przez Stanisława Piaseckiego; swoją tożsamość ukrywał pod pseudonimem „Witold Turno".

56 Tłumaczenie: „Umarł literat / narodził się Tarnawski”.

${ }^{57}$ Być może pod tym pseudonimem ukrył się Kazimierz Wierzyński. Wskazują na to dwie pierwsze litery imienia i pierwsza litera nazwiska. Wszakże nie wypadało podpisać się nazwiskiem pod tytułowymi obelgami. Za tą śmiałą hipotezą przemawia fakt bardzo sprawnego operowania słowem, a także znajomość literackich osiągnięć Wita Tarnawskiego.

${ }^{58}$ Fikcyjne doniesienia agencji pasowych odnoszą się do skandalu dietetycznego, którego ofiarą padł Kazimierz Wierzyński. Podczas gdy poeta dzielnie dotrzymywał dietetycznego rygoru panującego w lecznicy, jego koledzy - Julian Tuwim i Mieczysław Grydzewski - postanowili wystawić go na próbę, przesyłając mu przez cały miesiąc wymyślne produkty zakazane w regulaminie zakładu. Tuwim, chcąc przelicytować swą pomysłowością Grydzewskiego, wysłał do lecznicy żywe prosię, które wywołało sensację. E. Kruk-Rostańska, op. cit., s. 4; N. Tarkowska, op. cit., s. 239. 


\section{ZAT}

Zakładowa Agencja Telegraficzna

18 VIII 1937

Kazimierz Wierzyński ustanowił dwa rekordy polskie. I tak podczas gry w kręgle jednym rzutem powalił 18 kręgli, po czym jednym haustem skonsumował 22 knedle ze śliwkami. W ten sposób osiągnął 40 punktów.

\section{PAT}

Pocztowa Agencja Telegraficzna

Przy przyjeździe prosięcia doszło do poważnych zaburzeń pod bramą tryumfalną koło jadalni Zakładu. Tłumy kosowitów przełamały kordon, z czego korzystając miejscowe męty, wyjadły co rychlej cały deser. Adresat zdrów, prosię także.

ZAT

Żydowska Agencja Telegraficzna

Depesza własna.

Jak się dowiadujemy Związek Chrześcijańskich Kupców i Producentów branży mięsnej powołał Kazimierza Wierzyńskiego w poczet swych członków honorowych. W sprawie członkostwa nadawcy wysyłki redaktora Grydzewskiego powstały pewne trudności.

\section{ZAT}

Sprostowanie.

Znany ginekolog dr Arct Witold prosi nas o umieszczenie następującego oświadczenia: w związku z niedowierzającymi uśmieszkami i dwuznacznymi niedomówieniami na temat choroby p. K. Wierzyńskiego stwierdzam z całą świadomością i poczuciem odpowiedzialności; że choroba pana K. W. nie ma nic wspólnego z przybyciem świnki, - której zresztą płci nie ustalono.

Ag. Hawasa

18 VIII 1937

W związku z pogłoskami, że Kazimierz Wierzyński osiedla się na stałe w Kosowie i nosi się z zamiarem budowania tuż pod Zakładem Dra Tarnawskiego, bekoniarni, otrzymujemy od cechu kokosowskich rzeźników i masarzy zapewnienie, że wiadomość ta jest na razie przedwczesną.

Transkontinental

New York

19 VIII 1937

Przyjaciele i wierzyciele K. Wierzyńskiego w związku z założeniem nowego działu świńskiej produkcji K. Wierzyński, Norblin i Ska poczynili znaczne zakupy wywołując zwyżkę cen i ruch na Wall Street. 


\title{
JAT
}

Japońska Agencja Telegraficzna

20 VIII 1937

Pekin Nowa bekoniarnia w Kosowie otrzymała znaczniejsze zamówienia dla armii nankińskiej. Znani kapitaliści p. Szmatloch i Ewa Feines przystąpili do koncernu ${ }^{59}$.

HAT

Hollywood Agencja Telegraficzna

20 VIII 1937

Lwów

W. Ditterle ${ }^{60}$ znakomity reżyser firmy Warner Broothers ${ }^{61}$ przybywa do Kosowa dla podpisania kontraktu na sumę 50 tysięcy dolarów dla uzyskania wyłącznego prawa wyświetlania filmu „Moja maleńka”. W związku z powyższym p. K. Wierzyński codziennie rano o godzinie 4-tej trenuje ze świnką chodzenie po rosie.

Wiadomości ze świata

Z albumu pamiątkowego schroniska PTT „Tadeuszówka” w Żabiu Ilci jeden z kuracjuszów - badaczy obyczajów powiatu kosowskiego wypisał następujący autentyczny zapisek:

\author{
Najazd kosowitów \\ Nad nurtami Czeremoszu \\ Zajadamy się z rozkoszą \\ Szynka, wódka, masło, miody, \\ Świetne piwko - istne gody.
}

Następują podpisy uczestników:

M. T. z Gdyni, M. i T. T. z Warszawy, Z. N. z Krakowa ${ }^{62}$ i inni, wśród których czarno na białym stwierdzić można podpis: Dr Busza ${ }^{63} \mathrm{z}$ Kosowa. Pragnącym stwierdzić autentyczność zapisków poleca się przy sprzyjającej pogodzie zrobić wycieczkę pieszo, wozem lub autem. Sądzimy, że lepiej uwierzyć i na koszta się nie narażać.

59 Osoby niezidentyfikowane.

60 Właśc. William Dieterle. Niewykluczone, że celowo zniekształcono nazwisko tego niemieckiego aktora i reżysera, by podkreślić fikcyjność ogłoszenia.

${ }^{61}$ Poprawnie Warner Brothers. Być może umyślnie zniekształcono nazwę słynnej wytwórni filmowej.

62 Prawdopodobnie mowa tu o Zygmuncie Nowakowskim (1891-1963) - felietoniście, pisarzu, aktorze i reżyserze teatralnym. Jego obecność w lecznicy wspominała C. Tarnawska-Busza. Zob. Instytut Polski im. gen. Sikorskiego w Londynie, KOL 295: Wit Tarnawski, C. Tarnawska-Busza, Wspomnienie o moim Ojcu Drze Apolinarym Tarnawskim, s. 9.

63 Alfons Busza - absolwent medycyny Uniwersytetu Poznańskiego, od ok. 1936 r. asystent w kosowskiej lecznicy, od 1936 r. maż Celiny Tarnawskiej, z którą miał dwoje dzieci: prof. Andrzeja Buszę literaturoznawcę i poetę, oraz prof. Wita Buszę - fizyka. 
Komunikat Redakcji:

W jadalni przed pięknie graficznie wypisanym afiszem „Gong Głodomora” dyskutuje zebrany tłum kosowitów na temat autorstwa tego dzieła sztuki. Redakcja otrzymała w wyniku tego zapytanie, kto właściwie malował: Norblin, Buch czy Werner? ${ }^{64} \mathrm{Re}-$ dakcja przygotowuje odpowiedź i nie omieszka jej podać do publicznej wiadomości $\mathrm{w}$ następnym numerze.

Nadesłane

Pytało grubasów trzech

Jaki jest największy grzech?

$\mathrm{Na}$ to rzecze Senior zły:

Obżerać się tak jak wy.

I by zniszczyć wszelkie zło

Dał głodówki im dni sto.

Alina Kwiecińska

A czy pani już widziała

Tę co wczoraj przyjechała?

Jaka miła, sympatyczna,

Taka ładna - prawie śliczna -

Żeby tylko ręce krótsze,

Żeby nieco węższe w kuprze,

Zeza gdyby też nie miała

No i gdyby nie łysiała

Toby była pierwsza klasa -

Piękność, zdrowie: prosta rasa.

T. K.

Przyjechałam do Kosowa. Czytam nad bramą „Władaj sobą”. Myślę sobie - jest w tym pewno jeszcze jakaś myśl ukryta. Czytam od prawej ku lewej: „Ąbos Jadał w.” (widocznie w. znaczy: „wiele”). Aha: dla tego tu musiał trafić, ten Ąbos. A kto ten Ąbos nieszczęsny - niech się każdy domyśla ${ }^{65}$.

${ }^{64}$ Aluzja do nazwy warszawskiej spółki: „Towarzystwo Akcyjne Fabryk Metalowych” pod firmą „Norblin, Bracia Buch i T. Werner”. Stefan Norblin, który był autorem afiszu zawieszonego przed jadalną wywodził się z rodziny przemysłowców. Jego stryjeczny dziadek Wincenty Konstanty Norblin był założycielem fabryki.

${ }^{65}$ Gra słowna, którą trudno dziś zinterpretować. Prawdopodobnie „Ą” oznacza Apolinarego, zaś „bos” jest nawiązaniem do angielskiego słowa boss, czyli szef. Nad bramą wjazdową do lecznicy widniał napisał „Władaj sobą” zapowiadający obowiązujący w niej nakaz moralny, czyli kształtowanie silnej woli. 


\section{Z Zakładu \\ Obrazki i wrażenia}

\section{Biuro Zarządu}

(rzecz dzieje się niedługo po wschodzie słońca)

Zaspokoiwszy, w małej zresztą części, potężny apetyt, wszyscy kosowici bez różnicy płci, wagi i wieku runęli do Zarządu. Pani Micia ${ }^{66}$ nie zdołała jeszcze przełknąć ostatniego kawałka szynki, który dyskretnie wędrował z nią w torebce ręcznej do jadalni, - a już zgodnie ze wskazaniami Zarządu, musi nie tylko usiąść przy palisandrowym biurku z epoki Hrycia Jodłowego, lecz nadto zrobić tak uprzejmy wyraz twarzy na jaki jej wygimnastykowane mięsnie oblicza pozwalają. W imię sprawiedliwości należy dodać, że Pani Micia usiłuje uroczym swym uśmiechem i jasnością rozweselić ponury lokal Zarządu (zwłaszcza w chwilach wyrównywania rachunku). O tejże godzinie zasiada przy drugim biurku (o liniach miejscowych) osóbka młoda, pełna wdzięku tudzież „niezałatwionych spraw z dnia poprzedniego”. W kącikach jej oczu czają się ostatnie pieszczoty Morfeusza, z którego objęć zdołała dopiero co się wyrwać, a śladów którego nie zdołała jeszcze zatrzeć, wobec braku jej znajomości z pudrem i tuszem. Ot los robotnicy umysłowej! W ponurej tej komnacie „białych głów" unosi się duch administracyjnego satrapy, który w natłoku pracy zapomniał liczyć. Kosowici wywalili drzwi... Padają najrozmaitsze, najdziwniejsze i najmniej oczekiwane pytania: Proszę o świeczkę! Telefon do Mszany Dolnej - lecz zaraz. Czy nie zostawiłem tutaj mego parasola? Kto jest ta ładna pani, która siedzi na balkonie? Czy u pani dostanę jabłek? Gdzie jest mój mąż? Proszę o zmianę 10-ciu złotych, itd. Mimo nawału pytań pani Micia zachowuje heroiczny spokój i niezmąconą pogodę ducha. (Jej uśmiech to skarb niecodzienny). Dama pytająca o własnego męża dostawszy odpowiedź przeznaczoną dla chcącego zamienić pieniądz... „w Urzędzie Skarbowym"... wpada w szał i wylatuje w przewiewnym kosowskim mundurku w kierunku miasta. (Przez następne dwa dni męża tego nie widziano na gimnastyce). Rachityczny oddech samochodu kosowskiego zwiastuje przyjazd nowego gościa „Zygmunt!!!” i energicznie zaterkotał dzwonek. Z samochodu wylewa się coś na kształt kobiety i psa. Kto z nich więcej przepasiony nie wiadomo. Zawsze uprzejmy Zygmunt ${ }^{67}$, który nadbieżał na zew służbowy, wyładowuje pakunki i pakuneczki, pudła i pudełeczka, nesesery i neseserki wdzięcznej dwustukilogramowej damy i pasa. Pomruk Budrysa i Pumy decyduje o umieszczeniu damy z pieskiem poza Zakładem. Pani Micia przystępuje do urzędowego protokołu z gościem, o genealogię pieska nie pytając. Wszystko szło gładko, aż utknęło na rubryce wieku wobec stanowczego stwierdzenia damy (po raz szósty), że ma lat „dzieci”. Wobec tego pani Micia pisze „naście”. Dalej stan cywilny: wolny przy piesku. Stosunek do wojska: raczej poprawny. Kategoria „x” licząc od kostek do kolan... Oblężenie biura i powódź dezyderatów nie ustaje aż do chwili, kiedy gong nieubłagany odwołuje wszystkich do pracy, a wtedy i pani Micia

66 Osoba niezidentyfikowana.

67 Prawdopodobnie mowa tu o Zygmuncie Szikiercie, pracowniku lecznicy, który był zatrudniony w charakterze posłańca. Zob. N. Tarkowska, op. cit., s. 196. 
może spokojnie zasiąść do niby umysłowej, myślowej pracy fizycznej. A twarzyczka jej, wtedy to symbol zadowolenia ze siebie, z pracy i z wszystkich...

\section{KUPER}

Kosowskie Uniwersalne Przetwory Estetyczno-Regeneracyjne

polecają

kuracjuszom i kuracjuszkom pragnącym zmienić swe kształty, wielki wybór form plastycznych

dla osób różnego wieku, stanu i budowy

odlanych według renomowanych modeli piękności względnie wspaniałości: Formy (wklęsło-negatywy) przyodziewa się w chwili ukończenia głodówki i pozostaje się w nich najpierw przez całą dobę, potem tylko w nocy, aż do osiągnięcia pożądanych kształtów.

\section{Cennik}

model łącznie z wykonaniem formy... od 600 do $1000 \mathrm{zł}$.

Nabywając na własność uzyskują 10\% zniżki.

Przy wynajmie na jeden sezon do ceny modelu dolicza się 25\%. Poleca się modele: „Kazimierz”, „Rzegota” (dla starszych panów), „Witold” (nadaje się w szczególności dla młodych lekarzy - chirurgów), „Zofia” (model średni), „Wanda” (dla figur filigranowych), „Ewa” (dla finansjery).

\section{Do wszystkich kuracjuszy!}

Wobec nagminnego szerzenia się zarazy brydżowej, pożerającej codziennie dziesiątki ofiar (nie licząc kosztów) byłem zmuszony do zajęcia się sporządzenia szczepionki wyhodowanej na osobnikach beznadziejnie atakom tej choroby podlegającym. Od przyszłego sezonu każdy przyjeżdżający do Zakładu będzie zmuszony przy wstępnym badaniu u Dra Buszy poddać się szczepieniu ochronnemu. W sezonie obecnym z powodu deszczów i niezatwierdzenia surowicy nazwanej przeze mnie „antybrydżyną” szczepienia ochronne zastosowane zostały jedynie do dzieci niżej lat dwunastu ${ }^{68}$.

Dr Wit

\section{Pochwała Prałata \\ Panu G... poświęcam.}

Prałacik tu, prałacik tam

Bo prałat zawsze pośród dam

Czy brunetka, czy szatynka,

${ }^{68}$ Brydż był bardzo popularną rozrywką wśród inteligencji, ale zasady panujące w lecznicy zabraniały uprawiania gier hazardowych, które uważano za szkodliwy nałóg - stąd żart o szczepionce przeciwbrydżowej. W programie placówki pisano: „Nałogi są gorsze od chorób, bo trudniejsze do opanowania. (...) Najszkodliwsze jest palenie tytoniu, bo za nim idą inne, jak palenie tytoniu, łakomstwo i gra w karty". A. Tarnawski, op. cit., s. 21. 
Czy to ruda, czy blondynka

Wszystko jedno, byle była

Trochę ładna, trochę miła -

Zanim powie dowcip jaki

Wszystkie panny pieką raki

Wszyscy śmieją się wokoło

Bo z prałatem jest wesoło.

\section{Obrazki i wrażenia z kappieliska kosowskiego}

Dział „Dla pań”

W łazience żeńskiej ruch jak w ulu (trutni tutaj nie ma). Pod adresem słodkiej pani Anieli sypią się prośby, żądania i pytania. Tu masaż, tam kąpiel całkowita lub częściowa, gdzie indziej otrzepanie ręcznikiem, czy kąpiel falista, nasiadówka (to biorą panie chętniej wieczorami), lub tusz szkocki. Czasem pani Aniela musi uspokajać krzyki pań, zapewniając je, że wchodzący pies to Puma a nie Budrys. Kąpiel kąpielą, lecz rozmowa o bliźnich też uszlachetnia. To też poświęcają temu tematowi piękne kuracjuszki wiele czasu... Ach moja droga pani, strasznie lubię panią Lulę, ale nie wiem jak może się ona podobać prałatowi... Bo co? Przecież ma owłosione nogi... Ależ... prałata znam od lat dwudziestu... on za tym przepada. Jednocześnie przy masażu pod czułymi palcami pani Anieli otwierają się serca i dusze. Pani Aniela to spowiednik Zakładu, to lekarz zranionych serc... Pani Aniela umie pocieszać i rady dawać. Ach te zmarszczki... Nic nie szkodzi, rozmasuje się, to głupstwo... Jak pani dziś ślicznie wygląda. Doprawdy ma pani dzisiaj swój dzień i wygląd na 18 lat...

Jedna z pan radzi się co robić by mąż do niej się wrócił? Pani Aniela szepce na ucho: nie robić takich ponurych minek, słodko się uśmiechać, pani przecież jest młodziutka, prawie podlotek. Po naszych zabiegach mąż na pewno zakocha się na nowo. Co druga z obecnych pyta co robić by „te wdzięki nie opadały”. Odpowiedź na to jest standaryzowana: proszę paniusi gorące i zimne natryski na przemian; toż jedyna rzecz, - ręczę, że będą znowu dziewicze. Do łazienki wchodzą dwie nowe kuracjuszki dyskutując z zapałem ...ależ na pewno to nie jest jej mąż, to jej wuj. Może być moja droga, lecz oni mieszkają razem. To nic nie szkodzi. Wuj musi się opiekować siostrzenicą... Temu ostatniemu powiedzeniu towarzyszą uśmiechy więcej jak dwuznaczne. Z kąta dochodzi głos: proszę pani, czy pani widziała te pryszcze u pani Y. i co ona jeszcze bierze się do flirtu... i to z kim (reszta na ucho). Piękność siedząca na natrysku dolnym zachwyca się wraz z nimfą z kąpieli falistej Drem Witem: ...Ależ on jest wprost adorowany. Ciekawam co on lubi? Panny, czy mężatki? Cicho! Lepiej o tym nie mówić. W każdym razie czas by mu się ożenić a tu ani rusz. Słyszałam, że jedna pani pragnie go zapoznać z posażną osóbką, dwieście tysięcy w kieszeni - a on nic, twardy jak sucharek kosowski. Raptem robi się w łazience zamieszanie. Panna Lili mdleje. Pani Aniela chwyta ręcznik, kładzie omdloną piękną blondynkę na otomance. Lili omdlewającym głosem żąda doktora. Za chwilę wpada zaalarmowany doktor Busza. 
Damy w krzyk - popłoch ogólny... Zemdlona otwiera oczy a ujrzawszy doktora Buszę zrywa się z tapczanu z okrzykiem protestu... Ja chciałam doktora Wita.

Wieczory intymne.

$$
\begin{aligned}
& \text { Dancingi - Gabinety. } \\
& \text { CHEZ PONCAQUE }
\end{aligned}
$$

Koło mostu obok Kółka Rolniczego.

\section{OGLOSZENIA}

Za ten dział Redakcja pisma nie bierze żadnej odpowiedzialności.

Zawodowo pracujący pod halą (gimnastyczną) rębacz-głodomór poszukuje towarzyszki dla połączenia acetonowych westchnień ${ }^{69}$.

Skądinąd uczciwy mąż (czasem go boli głowa) odnajmuje w godzinach popołudniowych pokój własnoręcznie przez własną żonę urządzony. Cisza, słońce, wygoda i... dwa kilimy. Zgłoszenia „Willa Celina” litera S.”

Firma Baczewski chcąc iść na rękę zaleceniom doktora Wita dla nabrania cieplika przed zabiegiem wodnym, poleca (przez usta żeńskiej reprezentacji znanego domu alkoholowego) wszelkiego rodzaju trunki po cenach nie przekraczających możliwości picia i wypicia. Dla Zakładu w Kosowie poleca się 70\%-wą wódkę "Jaroszówkę" oraz wytrwaną „Rycynówkę”.

Kociu! Przybywaj do Kosowa. Ubyło mi dwadzieścia kilogramów. Miejsce na pięcioraczki kanadyjskie zapewniono. Asia.

Siamo! Czekaj w Kowlu. Przytyłem. Będziesz zadowolona. Nie zwlekaj. Tadupek. (pomyłka w druku nie wykluczona ${ }^{70}$.

Kobieta frontowa chce zmienić. Acetonowcy wykluczeni. Rendez-vous bezpośrednio po zabiegu. Zgłoszenia pod „Tępa Piła”.

O tyle o ile stuprocentowy mężczyzna, blondyn, czarne oczy, bicepsy nie fałszowane, podobno zdolny, poszukuje towarzyszki samotnych spacerów wśród kukurydzy po godzinie 10-tej wieczór, bez względu na pogodę. Konieczna znajomość zachowania się na widok doktorskiego reflektora. Zgłaszać pod „Na każdy sposób”.

Należytego traktowania dam uczy panów kąpielowa Zakładu. Dyskrecja zapewniona. Indywidulane rady i rewelacje.

${ }^{69}$ Podczas kuracji postem $\mathrm{z}$ ust pacjentów wydziela się nieprzyjemny zapach acetonu.

70 Dopisek redakcji w oryginale. 
Zaginęła córka źle straszona. Znak szczególny: wraca zawsze na posiłki do jadalni. Odszukanie bez nagrody. Wiadomość w Redakcji.

Tańców salonowych stylem angielskim tudzież boso bez względu na płeć, stan i wagę, wyucza pod gwarancją Zakład. Opłata ryczałtem z góry. Palenie i picie wzbronione. Parom niżej $50 \mathrm{~kg}$ łącznie Zakład wypłaca premię.

Obcinam bez bólu wszelkie kończyny jednym uderzeniem siekiery. Zgłoszenia „Grubasek", willa Szałas duży, pokój 6 .

Przystojna, miła blondyna mdleje podczas głodówki. Mocne męskie ramię poszukiwane. Zgłoszenie z załączeniem fotografii i zaświadczeniem sprawności fizycznej. Zwrot pod słowem honoru. Mieszka willa Ogrodowa.

Mogę odstąpić większa ilość lepszych i gorszych dowcipów dla pań i panów na każdą okoliczność. Zgłoszenia pod: „Żonaty chodzi w cywilu”: jadalnia litera J.

Blondyna, oczy niebieskie, temperament nie najgorszy, wzorowa matka (poza tym wróg mężczyzn) - poszukuje do swych dwojga przemiłych dzieciaków (Jerzy i Halinka) opiekuna lub opiekunki. Pragnie „czas wolny od dzieci” poświęcić sprawom godziwym. Wymagana żelazna ręka wobec dzieci a wyrozumiałość dla matki. Zgłaszać willa Ogrodowa pod „Mama”.

Pod nieobecność żony udzielam wypróbowanych wskazówek miękkiego, ale stanowczego traktowania panien, żon i rozwódek wszelkiej maści. Za skutek ręczę jedynie przy lekcjach indywidulanych. Na zamówienie wykonuję skecze dla teatrów stołecznych. Bliższe szczegóły stół drugi w jadalni. Zgłoszenia pod T. K. Szałas wielki.

Instytut heraldyczny. Genealogie wynajduję, parantele ustala zależnie od potrzeby, pewnie i solidnie, tak od przodków jak potomków. Znajomym i krewnym znaczny opust. Odpowiedzi udziela za pobraniem po nadesłaniu zaliczki. Adres Anni - Jadalnia 15.

Duchy wywołuje, na jawie i we śnie, w dzień i w nocy, we dwójkę i solo. Pp. D. i Wleklińska.

Uczę gry w kręgle. Zgłaszać pod „Papa-Klapa” willa Jasna.

À la minute maluję pokoje i akty z należytym smakiem. Zgłoszenia pod U. stół główny. 
Doświadczony urzędnik służby zagranicznej uczy szoferowania systemem amerykańskim. Tamże lekcje brydża, flirtu, bilardu i innych powinności towarzyskich. Zgłoszenia pisemne pod „Caveant Consules”

Poprawiam i reperuję malowidła od Van Dycka do Umińskiego. Ceny śmiesznie małe. Zapewniam wygląd naturalny w każdym odcieniu. Zgłaszać przed wyjazdem z Zakładu w willi Głównej, pierwsze piętro pod $\mathrm{R}^{72}$.

\section{Książki mówią}

Karol Populakiewicz Kosów. „Jak zdobywać popularność” stron 5 - cena według umowy. Nakład autora.

„Pod umówioną Buszyną” zbiór pieśni międzydzielnicowych, zebrała i opracowała C. T. B ${ }^{73}$.- do nabycia w Zarządzie Zakładu.

„Wrażenia z podróży poślubnej” podręcznik dla lekarzy krajoznawców. Opracował $\mathrm{dr} \mathrm{B}^{74}$.

\section{Kina}

Kino Jadalnia: „Hrabina Luxemburg” czyli „Dobre plecy” dramat kryminalno-erotyczny w jednym - ale dobrym akcie - raczej długometrażówka.

Operetka zakładowa wystawia:

\section{Teatry}

\section{BARON CYGAŃSKI}

w jednym akcie

z Miro Chłapowskim ${ }^{75}$ w roli tytułowej

muzyka pod batutą p. Krotkiewskiego.

Po kuracji kosowskiej najlepiej

u TRUCHANOWICZA

${ }^{71}$ Ogłoszenie nawiązuje prawdopodobnie do osoby Wiktora Podoskiego, który był w tamtym czasie pracownikiem Ministerstwa Spraw Zagranicznych.

72 Fikcyjne ogłoszenia o żartobliwej treści odnoszą się do pacjentów przebywających na kuracji w lecznicy podczas redagowania pisma. Kluczem do zidentyfikowania osób, które rzekomo były autorami ogłoszeń, było podanie w ogłoszeniu miejsca ich zakwaterowania. Niestety, obecnie nie posiadając tej wiedzy, nie jesteśmy w stanie dokonać identyfikacji.

73 Aluzja do nazwiska Celny, po mężu (Busza), ale również do tego, że do 1914 r. lecznica stanowiła miejsce spotkań dla Polaków z trzech dzielnic rozbiorowych.

${ }_{74}$ Nawiązanie do podróży poślubnej Celiny Tarnawskiej-Buszy i dra Alfonsa Buszy, którzy pobrali się w $1936 \mathrm{r}$.

${ }^{75}$ Kazimierz Chłapowski pseud. „Miro” (1896-1976) - pianista, studiował w konserwatorium w Dreźnie i w Paryżu. 


\section{Od Redakcji:}

Do pierwszego egzemplarza „Gonga Głodomora” nr 2 dołączono trzy oryginalne rysunki Stefana Norblina, a to: portret dra Wita Tarnawskiego, Kazimierza Wierzyńskiego, prof. Chrzanowskiego.

Całość wydana na zasadach rękopisu. Naśladownictwo zastrzeżone.

$$
\begin{array}{r}
\text { Redakcja i Administracja } \\
\text { Z poważaniem } \\
23 \text { VIII } 1937
\end{array}
$$

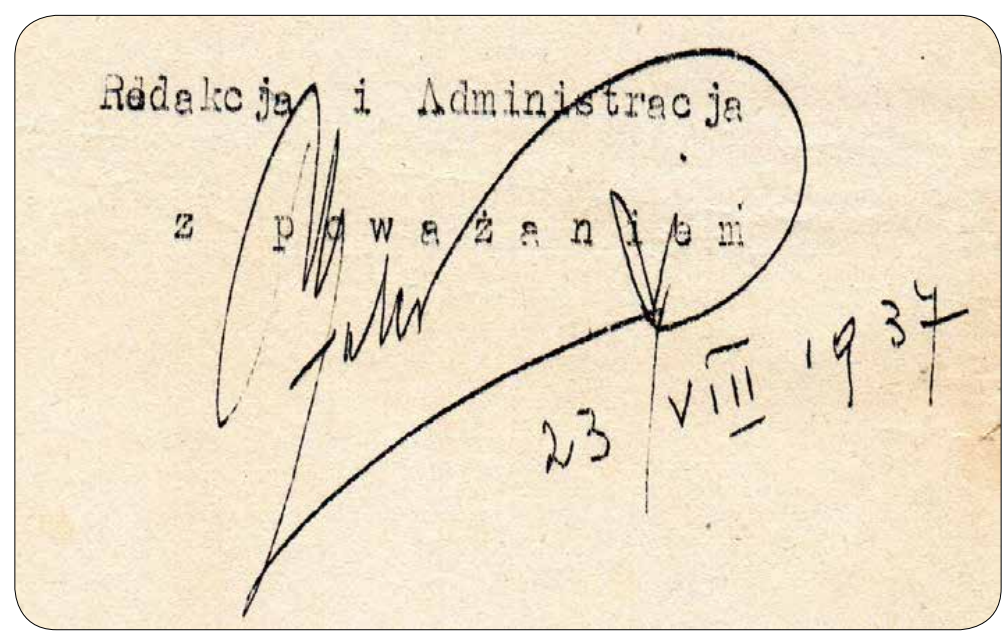

6. Prawdopodobnie autograf redaktora Wojciecha Zaleskiego.

Źródło „Gong Głodomora” 1937, nr 2, s. 21.

\section{Bibliografia}

\section{Źródła archiwalne:}

Archiwum rodzinne Adama Śmiarowskiego

Życiorys Alfreda Śmiarowskiego, rkps.

Instytut Polski im. gen. Sikorskiego w Londynie

KOL 295: Wit Tarnawski, C. Tarnawska-Busza, Wspomnienie o moim Ojcu Drze Apolinarym Tarnawskim, mps.

${ }^{76} \mathrm{~W}$ tym miejscu znajduje się odręczny podpis redaktora „Gongu Głodomora” - najprawdopodobniej W.J. Zaleskiego. 


\section{Zbiory autorki}

Korespondencja Adama Śmiarowskiego z autorką, 24 XI 2016 r.

\section{Źródła drukowane:}

Informator Ziemi Kosowskiej, Kosów 1935.

Tarnawski A., Program Zakładu Przyrodoleczniczego Dra Tarnawskiego w Kosowie k. Kołomyi Młp. Wsch., Lwów 1933.

\section{Wspomnienia:}

Kruk-Rostańska E., Jeszcze o Kosowie. Do redaktora „Wiadomości, „Wiadomości” (Londyn) 1950, nr 18 (213), s. 4.

Piasecki S., O imienniku z Świętego Krzyża, „Prosto z Mostu” 1937, nr 37, s. 1.

Tarnawski W., Mój ojciec, Londyn 1966.

Wieniewski I., Kalejdoskop wspomnień, Londyn 1970.

Prasa:

„Prosto z Mostu” 1937.

\section{Opracowania:}

Dobroński A., Krasomówca rodem z Łomży, „Kontakty” 1982, nr 9, s. 11.

Gąsiorowski H., Przewodnik po Beskidach Wschodnich, t. 2, Lwów-Warszawa 1933.

Kania L., Wspomnienie o adw. Eugeniuszu Śmiarowskim (1878-1932), „Palestra” 2005, nr 1112, s. 138-142.

Łoza S., Czy wiesz kto to jest?, Warszawa 1938.

Puto K., Zdroje Truskawieckie jako organ autokreacji kurortu wypoczynkowego, [on-line:] http://docslide.pl/documents/zdroje-truskawieckie-jako-organ-autokreacji-kurortu-wypoczynkowego.html\#, odczyt: 16 II 2017.

Pruszyńska A., Topolska M.B., Tarnawski Wit, [w:] Encyklopedia polskiej emigracji i Polonii, t. 5: $S-\dot{Z}$, red. K. Dopierała, Toruń 2005, s. 109-110.

Tarkowska N., Lecznica narodu. Kulturotwórcza rola Zakładu Przyrodoleczniczego doktora Apolinarego Tarnawskiego na Pokuciu (1893-1939), Kraków 2016.

Topolska M. B., Tarnawska Busza Celina, [w:] Encyklopedia polskiej emigracji i Polonii, t. 5: S-Ż, red. K. Dopierała, Toruń 2005, s. 108-109.

Zbyszewski K., Stanisław Piasecki, [w:] Straty kultury polskiej, t. 1, red. A. Ordęga, T. Terlecki, Glasgow 1945, s. 370.

Наталія Тарковьска, «Гонг ненажери» - гумористичний образ інтелектуальної атмосфери і звичаїв у Природолікувальному закладі доктора Аполінарія Тарнавського в Косові

«Гонг ненажери» $є$ унікальним екземпляром сатиричного неперіодичного видання у вигляді машинопису під редакцією пацієнтів Лічниці натуральної медицини доктора Аполлінарія Тарнавського в Косові на Покутті, розташованої на території колишньо- 
го Станіславівського воєводства (нині Івано-Франківська область, Україна). Лічниця, яка функціонувала в 1893-1939 роках, була важливим центром польської культурного життя в Східних кресах. Будучи популярним місцем відпочинку, призначеним для інтелігенції, вона стала ідеальним полем для стимулювання розвитку літературної та художньої творчості. Збережений текст був створений видатними літераторами, письменниками, поетами і художниками, такими як: Казімєж Вєжинський, Віт Тарнавський, Стефан Норблін, Віктор Подольський, Войцех Залеський чи професор. Ігнатій Хшановський - які перебували в Косові на лікуванні влітку 1937 р. 3 відредагованого рукопису з'являється яскрава картина польського інтелектуального життя 30-х років XX століття. Крім того, текст приносить нам знання про те, яким формам розваг віддавала перевагу еліта під час відпочинку в курортних місцевостях. Знайдений машинопис, без сумніву, є важливим джерелом для дослідження про інтелектуальний внесок і культурний доробок косівської лічниці у розвиток вітчизняної культури.

Ключові слова: Аполінарій Тарнавський, Віт Тарнавський, Ігнатій Хшановський, Казімєж Вєжинський, Стефан Норблін, Косів, польські курорти на Східних кресах, сатирична періодика, міжвоєнний період

Natalia Tarkowska, „Starveling's Gong”- Humorous Picture of the Intellectual Atmosphere and Customs in the Natural Medicine Centre of Dr Apolinary Tarnawski in Kosow

Starveling's Gong is a unique copy of a satirical piece in the form of a typewritten journal edited by the patients of the Natural Medicine Centre of Dr Apolinary Tarnawski in Kosow in Pokkuttya. The Natural Medicine Centre was located on the territory of the former Stanisławow Voivodeship (currently Ivano-Frankivsk Oblast, Ukraine). The centre, active in 1893-1939, was one of backbone of Polish cultural life in the Borderlands. As a popular holiday destination for the intelligentsia, it became an ideal platform for stimulating literary and artistic creativity. The preserved text was created by prominent writers, poets and artists, such as: Kazimierz Wierzyński, Wit Tarnawski, Stefan Norblin, Alina Kwiecińska, Wiktor Podoski, Wojciech Zaleski or prof. Ignacy Chrzanowski, who all stayed in Kosow for treatment in the summer of 1937. From the edited manuscript provides a vivid image of the Polish intellectual activity in the 1930s. In addition, the text brings us closer to fuller knowledge about what entertainment the elite provided themselves during the stay in health resorts. The retrieved manuscript undoubtedly inspires further research into the intellectual contribution and cultural achievements of the medical centre in Kosow for the development of the native culture.

Keywords: Apolinary Tarnawski, Wit Tarnawski, Ignacy Chrzanowski, Kazimierz Wierzyński, Stefan Norblin 